$\overline{\text { 報交 }}$

\title{
延伸ポリエチレンテレフタレート・フィルム の熱収縮とその温度低存性
}

\author{
群馬大学工学部 加藤 俊夫 ・山本雄三 \\ 斉藤安史・木下茂武
}

\begin{abstract}
TEMPERATURE DEPENDENCE OF THE THERMAL CONTRACTION OF ORIENTED POLY(ETHYLENE TEREPHTHALATE) FILMS
\end{abstract}

By Toshio Kato, Yuzo Yamamoto, Yasushi Satto and Shigetake Kinoshita

(Faculty of Engineering, Gunma University, Kiryu-City, Japan)

Highly drawn poly(ethylene terephthalate) (PET) films were crystallized in air at $T_{a}=130-180^{\circ} \mathrm{C}$ for one hour. These films (named O.S.) shrunk freely by heating in air at $T_{c}=200,220$ and $230^{\circ} \mathrm{C}$ for $30 \mathrm{~min}$. and the changes in $\chi$ (degree of crystallinity), $\bar{D}$ (Scherrer's size of crystallite), $L$ (long period), $f$ (X-ray orientation degree), $l$ (length of film) and $S$ (thermal shrinkage) were traced. Plotting these parameters against $\Delta T_{r}=T_{C}-T_{a}$, changes in temperature causing films to contract, the following results were obtained:

(1) Relation between $S\left(T_{C}\right.$ ) and $\Delta T_{r}$ was approximately linear (Fig. 5).

(2) The rate of increment of $\chi, \bar{D}, L$ was nearly proportional to $\Delta T_{r}$ (Fig. 4, Fig. 7-9 and Fig. 13).

(3) The rate of decrement of $n=1 / \bar{D}_{\text {Tos }}$ and the rate of increment of $r=\left(L-\bar{D}_{\text {Tos }}\right)$ was also nearly proportional to $\Delta T$, (Fig. 11 and Fig. 18).

The results of (1) and (2) showed that the higher the degree of crystallinity of O.S., the lower the amount of shrinkage decreased. Assuming the structure of the annealed PET film as the two-phase model of alternating crystalline and non-crystalline regions, the results of (2) and (3) indicated that thicknesses of each lamellar and inter-lamellar regions $\left(\bar{D}_{\overline{1} 05}\right.$ and $r$ ) increased on contraction thermally, whereas the numbers of layers of lamellae $(n)$ in the drawn direction of film became smaller. These contractive behaviors seemed to be reasonable compared with the temperature ranges of crystallite-recrystallization into lamellae of PET films ${ }^{2)}$.

(Received January 13, 1976)

\section{1. 序論}

ポリエチレンテレフタレート(PET)は，延伸による 配向組織の形成と，熱処理による再組織化が，他のポり マーにくらべて比較的観察されやすい特徴があ $\eta^{1,2)}$, 熱

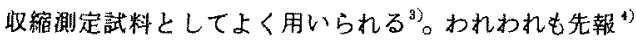

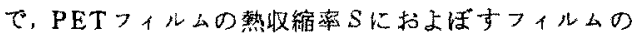
延伸比入の影響について報告した。そしてえ=2.5 付近で $S$ の值がmax.となることを示した。この結果は次のよう に説明される。すなわち熱收䧽の前および後のフィルム 長をそれぞれ $l=\lambda l_{0}\left(l_{0}\right.$ 壮末延伸原長)および $l^{\prime}$ とすると，
収縮率 $S=\left(l-l^{\prime}\right) / l$ と原長への回復率 $R=\left(l-l^{\prime}\right)$ $\left(l-l_{0}\right)$ とのあいだには

$$
S(\lambda)=\left(1-\lambda^{-1}\right) R(\lambda)
$$

の関倸がある。ここで式(1)の右边 $\left(1-\lambda^{-1}\right)$ は につれて増大寸るのに対して， $R(\lambda)$ の値は $\lambda=2 \sim 3$ 以 上の試料では急激に減少する傾向を示す。このためS( $(\lambda)$

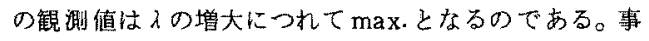
実 $\lambda=1 \sim 2$ の低延伸PET では，ひずみの大部分が無定

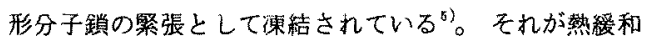
することによってRの値はほぼ $100 \%$ あるる。これに対 して, 高延伸されたス>3の試料では, 配向組織が強固 
で自由長熱処理におけるRの值は20\%以下にずない。 本報の主たる目的は，上述の後半すなわち高延伸配向 組織の强固さと熱緩和との関保至さらに詳しく検討する ことである。このため，延伸PETフィルム $(\lambda=3.6)$ を 予的 $T_{a}=130$ - 180 $\mathrm{C}$ の所定温度で定長熱処理し, 結晶 化度が異なるといら意味で“強固さ”の違った配问組織 をつくり、これらを取縮率測定の original sample(以 下O.S.と呼多)とした。O.S. 性 $T_{c}=200 \sim 230^{\circ} \mathrm{C}$ の高温 域で自由長熟処理した。このとき収縮率Sの値は，式(1) でスが一定であるから，直接にに比例する。収縮の前と 後とに扔ける配向組織の構造単位の大いさとしてはX線 測定によって溦結晶のサイズ，長周期などを求めた。そ して温度 $T_{a}$ から $T_{c}$ にいたる熱緩和の機構を，Sの值か 温度差 $\Delta T_{r}=T_{c}-T_{a}$ に比例して增大寸ることに着目して，

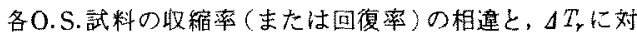
する構造単位の大いさの变化割合とを比較対応しつつ考 察した。

本報で選んだ $T_{a}, T_{c}$ の熱処理䋹度は， $T_{a} て ゙$ fold 晶の

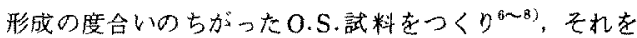
$T_{c}$ で部分融解を㧍こして再組織させることに相当する

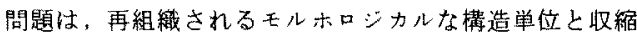
との関係である。えられた結諭からいえば，それは fold 晶がラィラ状の層状組織を形成して周围の緩和分子鎖を とりこみながら成長する過程である。同様なィカニズム はPETのみでなく他の配向ポりマー，たとえばポりエ チレンなど19)にも適用できると考えられる。ただしわれ われの結果は，配向PETの熱收維が無定形域の緩和で 定题的に取扱えるとするSamuels" の説とは異ってい る。

\section{2. 実馀}

2.1 試 料

未延伸 PETフィルム(帝人製)，厚さ $0.35 \mathrm{~mm}$ ，幅 15 $\mathrm{mm}$ 東洋測器製テンシロンを用いて，室温でネッキン グ延伸した。ゲージ長 $30 \mathrm{~mm}$ ，延体速度 $40 \mathrm{~mm} / \mathrm{min}$, 延伸比入=3.6である。ネッキング後の配向フィルムは透 明かつ均一で，その亦ま状熊で 15 分間放固，緩和さ せてゲーシから取り外した。

配向フィルム怯，結晶化度を変えるため $T_{a}=130 ， 150$ ， $160,170,180^{\circ} \mathrm{C} の$ 各温度で空気恒温槽内で定長熱処理 をおこなった。熱処理時間は $\iota_{a}=1 \mathrm{hr}$ とし, 直ちに氷水 中で急冷した。これを木りジル試料(O.S.)とした。

O.S.を空気中で $T_{c}=200 ， 220 ， 230^{\circ} \mathrm{C}$ の各温度で自 由長熱処理して，収縮武料とした。処理時間は収縮が平 衡に達すると認められた $t_{c}=30 \mathrm{~min}$ とし，その状態を保 つた氷水中で急泠した。

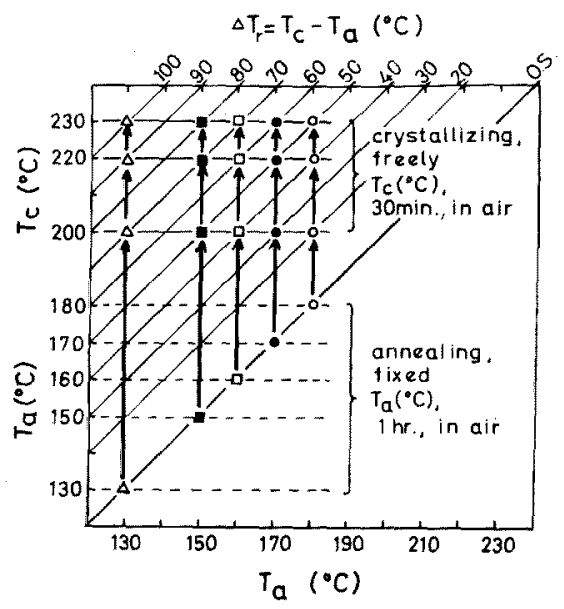

Fig. 1 Heat treatment paths used in the preparation of experimental PET films.

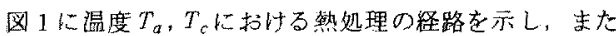
O.S.試料の熟焣理温度 $T_{a}$ とそれ 5 の試料の収維温度 $T_{c}$ との温度差の大いさ $\Delta T_{r}=T_{c}-T_{a}$ の值を付記した。 $\Delta T_{r}$ は組織が熱緩和するばあいの刺激の程度を表わしている。

\section{2 実験方法}

（1）收繀率測定 自由長熱処理前绫のフィルム長汃ら，

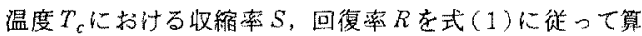
出した。 $\lambda=3.6$ として $S=0.72 R$ の関係がある。

（2）密度測定 nーヘプタン一四塩化炭素保の密度勾 配管を使い，30 $\mathrm{C}$ で密度 $。$ を測定した。結晶化度は体皘 分率 $\chi_{v}=\left(a-\rho_{a}\right) /\left(\rho_{c}-\rho_{a}\right)$ 上重量分率 $\chi_{w}=\left(\rho_{c} / o\right) \chi_{v}$ 上 について，結萌㧍よび非晶の密度をそれでれ。 および $\rho_{c}=1.335\left(\mathrm{~g} / \mathrm{cm}^{3}\right)$ として算出した ${ }^{12)}$ 。

（3）広角X線回折理学電機製の RU-3型の装置を用 い， 105 配向倸数 $f$ ，微結晶サイズ $\bar{D}$ 測定した。配向 保数は 105 回折ビークの皘分幅 $\mathrm{H}^{\circ}$ を求め, Dumbletom の方法によって $て^{13)} f=\left(180^{\circ}-\mathbf{H}^{\circ}\right) / 180^{\circ}$ 加方算出した。 微結晶サイズ からScherrerの式を用いてそれぞれの方向のものを求 めだ。すなわ告波舆 $\lambda ， \mathrm{Bragg}$ 角 $\theta ， \beta=K \lambda / \bar{D} \cos \theta$ で，KはScherrer の定数として0.95を採用し， $\beta$ は $=B^{2}-b^{2}$ としてWarren 補正を行った。Bは実測半価幅,

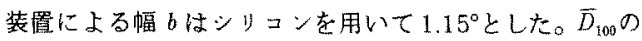
值は，微結昆断面が棈円であるとして，三斜晶系を考虑 して $\bar{D}_{010}, \bar{D}_{\tilde{1} 10}$ の值加ら推定した。

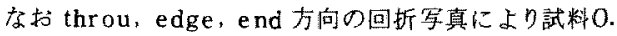
S.は面配向していないことを確めた。

（4）小角X線回折 理学電機製のRU-3型と付属 $2 \mathrm{C}$ 型の装置により小角回折像の写真を得，回折写真加ら 
Bragg 式を用いて長周期 Lを求めた”。 $L$ の值は処理 温度に対する相対的な変化值が問題となるため，湘定の 便法として写真法を用いた。

（5）愁則定 Perkin-Elmer DSC-IB 型を使って サーモグラムを得た。試料量 $4 \mathrm{mg}$ ，昇缊速度 $16^{\circ} \mathrm{C} / \mathrm{min}$ 。 標凖物質にはインジウムを用いた。

\section{3. 結果および考察}

\section{1 結晶化度と奴縮率との関係}

結晶化度の異なる試料O.S.を嗢度 $T_{c}$ で收縮させたと きの，重量分率結晶化度 $\chi_{c, w}$ 拉よび收縮率 $S$ の值の变化 を，図1の $\left(T_{a} ， T_{c}\right)$ 面上にブロットして，それぞれ図 2 および因了に示した。O.S.は $T_{a}$ の高いはど結晶化度 が大きく、この結晶化度の大きいもの怯，T坛にいて 収維率が小さい。いかかえれば，収縮後の結晶化度の增 加 $\Delta x_{w}\left(T_{c}\right)=\chi_{w}\left(T_{c}\right)-\chi_{w}\left(T_{a}\right)$ が小さいものは取縮率 $S$ が小さい。そこで $\Delta T_{r}=T_{c}-T_{a}$ の温度差に対して， $\Delta x_{w}$ $\left(T_{c}\right) / x_{w}\left(T_{a}\right)$ 扩よび $S\left(T_{c}\right)$ の值を四示すると四 4 およ び汹 5をうる。

雨者とも $\Delta T_{r}$ に比例し，勾配の檤はをれぞれ $4.1 \times 10^{-3}$ ， $1.57 \times 10^{-3}$ である。これらを収濰の嗢度原数 $s$ ，結昆化 度の温度保数 $\kappa_{w}$ と定義すると

$$
\begin{aligned}
& l^{\prime}=l\left(1-s \Delta T_{r}\right), \quad s=0.157 \pm 0.012\left(\% \mathrm{deg}^{-1}\right) \\
& \chi_{w}\left(T_{c}\right)=\chi_{w}\left(T_{a}\right)\left(1+\kappa_{w} \Delta T_{r}\right), \chi_{w}=0.41 \pm 0.035(1 ")
\end{aligned}
$$

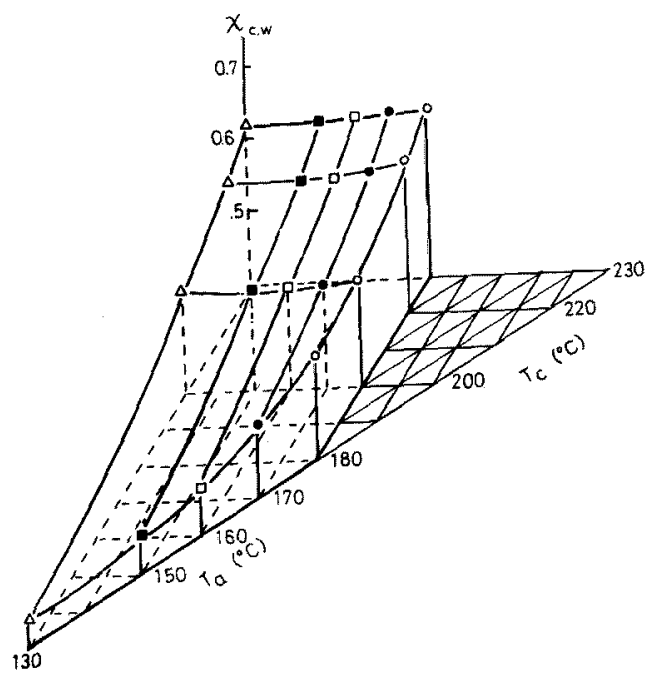

Fig. 2 Variation of the crystallinity (wt. fraction), $\chi_{c . w}$, with the heat treatment path, $\left(T_{a} \rightarrow T_{c}\right)$.

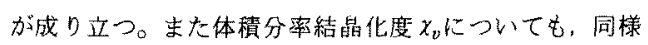
なプロットにより

$$
\chi_{y}\left(T_{c}\right)=\chi_{p}\left(T_{a}\right)\left(1+\kappa_{y} \Delta T_{r}\right), \kappa_{v}=0.35 \pm 0.051(1)
$$

をうる。

ここで延伸PETの構造が結晶と非晶とからなる值列 2 相モデルで表わされるとして，仮りに収縮が非晶のみ で行なるれるならば $\chi_{v}\left(T_{c}\right) / \chi_{v}\left(T_{a}\right)=l / l^{\prime}$ であって

$$
\left(1+\kappa_{v} \Delta T_{r}\right)=1 /\left(1-s \Delta T_{r}\right)
$$

の関倸がある。 $\Delta T_{r}=100^{\circ} \mathrm{C}$ として式 (2)(4)のs，瓜,

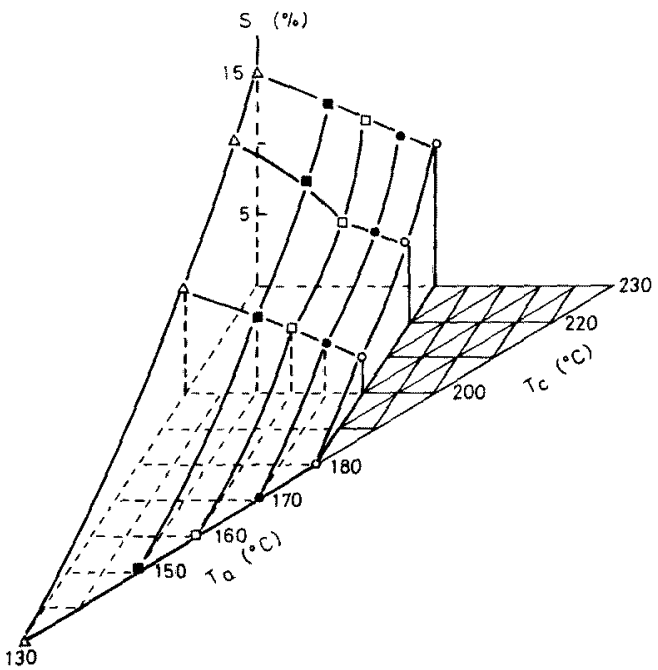

Fig. 3 Variation of the thermal shrinkage $(S)$ with the heat treatment path $\left(T_{a} \rightarrow T_{c}\right)$.

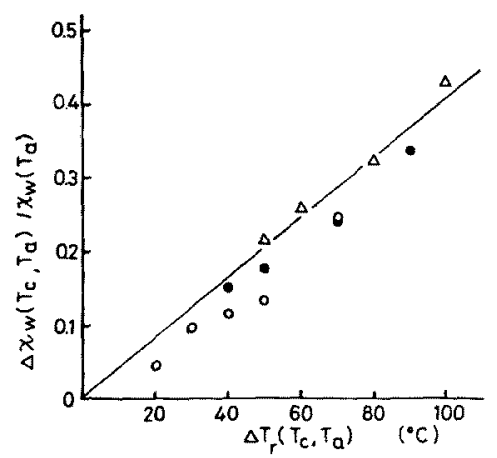

Fig. 4 Relation between the rate of increment of crystallinity, $\Delta \chi_{w} / \chi_{w}$, and the heat treatment temperature change, $\Delta T_{r}=T_{c}-T_{a}, O\left(T_{c}=200{ }^{\circ} \mathrm{C}\right)$, - $\left(T_{c}=220^{\circ} \mathrm{C}\right), \Delta\left(T_{C}=230^{\circ} \mathrm{C}\right)$. 


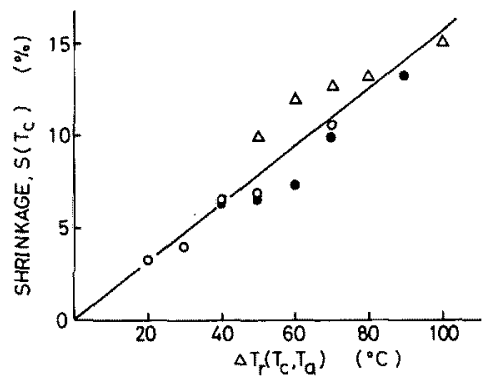

Fig. 5 Change of the thermal shrinkage, $S\left(T_{c}\right)$, with the difference of heat treatment temperature, $\Delta T_{r}$. $O\left(T_{c}=200^{\circ} \mathrm{C}\right), \quad\left(T_{c}=220^{\circ} \mathrm{C}\right), \Delta\left(T_{c}=230^{\circ} \mathrm{C}\right)$.

値を用いると，結晶化度の增加比は，式(5)の(左辺) abs $=1.35$ に﨎し(右辺) $\mathrm{cal}_{\mathrm{a}}=1.19$ となり観測値は計算値の 1.14 倍になる。誤差範囲以上のこの不一致は，O.S.の 算温による結晶の成長を考虑しないことに因っており， O.S.の取縮を単純に非晶の収縮に㷌着させえないこと を示す。

3.2 微結晶サイズ, 長周期の变化を考慮したと きの結晶化度と収縮率との関係

105 配向保数 $f$ は，図6に示したように，O.S.では 結晶化度の大きいものほど增大して $f=0.85 \sim 0.9$ の範囲 にあり，収樎試料はすべて $f>0.9$ てるる。こで各試料 の延伸軸方向の微結晶サイズを $D_{1}$ とし，これに垂直な 2 方向のものを $D_{2}, D_{9}$ とすれば，これらの値はそれぞれに ついて観測値 $\bar{D}_{106} ， \bar{D}_{100} ， \bar{D}_{010}$ で近似的に表示される。各

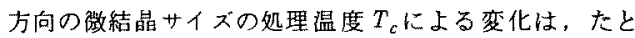
えば $\left(T_{a}, T_{c}\right)$ 座標上に $\bar{D}_{106}$ をプロットしてみると $T_{c}$ の增 加とともに增大している。そしてO.S.に対する变化割 合 $\left(\bar{D}\left(T_{c}\right)-\bar{D}\left(T_{a}\right) / \bar{D}\left(T_{a}\right)\right.$ を求西之, 图 7 に示した ようにっこのばあいも $\Delta T_{r}=T_{c}-T_{a} に$ 比例している。す なわち

$$
\begin{aligned}
& D_{1}\left(T_{c}\right)=D_{1}\left(T_{a}\right)\left(1+\alpha_{1} \Delta T_{r}\right), \\
& \alpha_{1}=0.38 \pm 0.11\left(\% \mathrm{deg}^{-1}\right)
\end{aligned}
$$

である。同様に $D_{2}, D_{9}$ についても

$$
\begin{aligned}
& D_{2}\left(T_{c}\right)=D_{2}\left(T_{a}\right)\left(1+\alpha_{2} \Delta T_{r}\right), \\
& \alpha_{2}=0.78 \pm 0.18(" \|) \\
& D_{3}\left(T_{c}\right)=D_{3}\left(T_{a}\right)\left(1+\alpha_{3} \Delta T_{r}\right), \\
& \alpha_{3}=0.53 \pm 0.068(" \|)
\end{aligned}
$$

の関係がある(図 8，図 9)。

収綟にさいしての数結晶サイズ $D_{1}$ の增加を，前節の 直列モデルに追加して，結晶化度の変化を求めれば， $x_{v}$ $\left(T_{c}\right) / x_{v}\left(T_{a}\right)=\left(l / l^{\prime}\right)\left\{D_{1}\left(T_{c}\right) / D_{1}\left(T_{a}\right)\right\}$ であって. 式(5)の代りに

$$
\left(1+\kappa_{y} \Delta T_{r}\right)=\left(1+\alpha_{1} \Delta T_{r}\right) /\left(1-s \Delta T_{r}\right)
$$

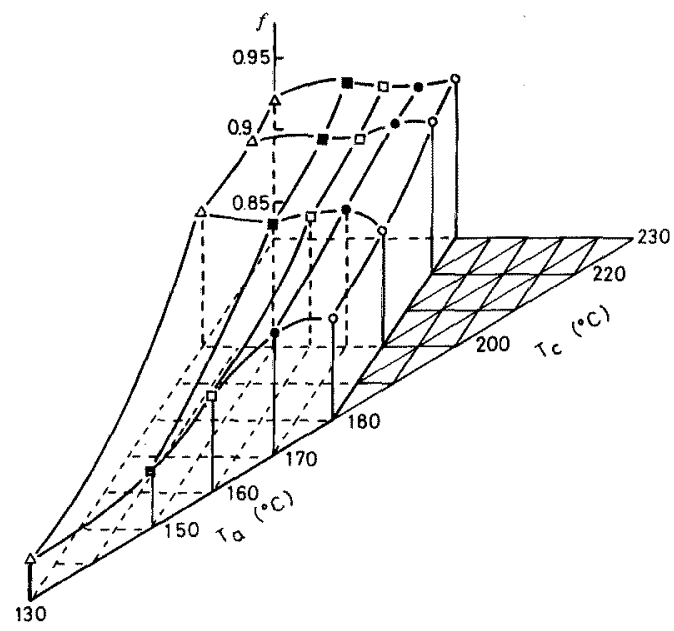

Fig. 6 Variation of the degree of orientation $(f)$ with the heat treatment path $\left(T_{a} \rightarrow T_{c}\right)$.

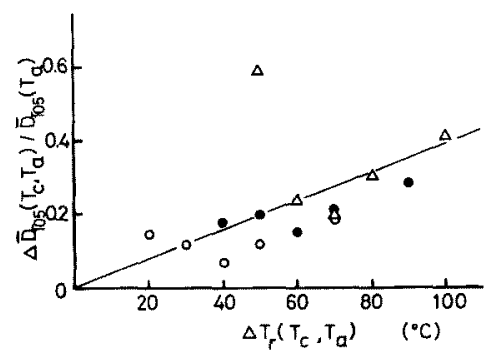

Fig. 7 Relation between the rate of increment of crystallite size, $A \bar{D}_{\overline{1} 0 s} / \bar{D}_{\overline{1} 0 s}$, and the heat treatment temperature change, $\Delta T_{r}=T_{c}-T_{a}$. $O\left(T_{c}=200^{\circ} \mathrm{C}\right), \quad\left(T_{c}=220^{\circ} \mathrm{C}\right), \Delta\left(T_{c}=230^{\circ} \mathrm{C}\right)$.

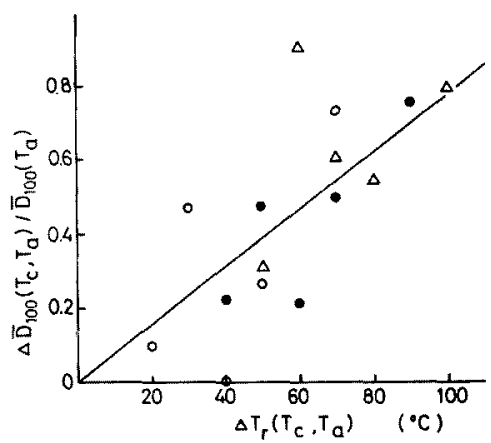

Fig. 8 Relation between the rate of increment of crystallite size, $\Delta \bar{D}_{100} / \bar{D}_{100}$, and the heat treatment temperature change, $\Delta T_{r}=T_{c}-T_{a}$. $O\left(T_{c}=200^{\circ} \mathrm{C}\right), \quad\left(T_{c}=220^{\circ} \mathrm{C}\right), \Delta\left(T_{c}=230^{\circ} \mathrm{C}\right)$. 


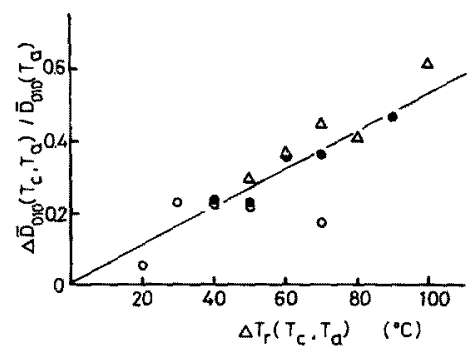

Fig. 9 Relation between the rate of increment of crystallite size, $\Delta \bar{D}_{010} / \bar{D}_{010}$, and the heat treatment temperature change, $\Delta T_{r}=T_{c}-T_{a}$. $O\left(T_{c}=200^{\circ} \mathrm{C}\right), \quad\left(T_{c}=220^{\circ} \mathrm{C}\right), \Delta\left(T_{c}=230^{\circ} \mathrm{C}\right)$.

をうる。温度保数 $\alpha_{1}, s \sigma$ 值を用い, $\Delta T_{r}=100^{\circ} \mathrm{C}$ につい て子ると式 $(9)$ の(右辺) $\mathrm{cal}=1.64$ となる。この值は前 とは逆に(左辺) obs $=1.35$ にくらべて大きすぎるさら に3次元的な結晶サイズの成長を考虑して、武料の体䅡 を温度 $T_{a}, T_{c}$ てそれる゙れ $v ， v^{\prime}$ とすると，淔列もデルに よる結晶化度の増加比は

$$
\begin{aligned}
& \chi_{v}\left(T_{c}\right) / \chi_{v}\left(T_{a}\right) \\
& \quad=\left(v / v^{\prime}\right)\left\{D_{1} D_{2} D_{3}\left(T_{C}\right) / D_{1} D_{2} D_{3}\left(T_{a}\right)\right\}
\end{aligned}
$$

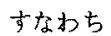

$$
\left(1+\kappa_{v} \Delta T_{r}\right)=\left(v / v^{\prime}\right)\left\{1+\left(\alpha_{1}+\alpha_{2}+\alpha_{3}\right) \Delta T_{r}\right\}
$$

となる。このばあい右辺の中括弧内の值は $\Delta T_{r}=100^{\circ} \mathrm{C}$ に対して 2.69 であって右辺の観測值が 1.35 でること から $v / v^{\prime}=1 / 1.99$ になる。この結果は収縮俊の試料体 皘がO.S.の約 2 倍となることを示し、明らかに実鮯事実 ${ }^{14)}$ $\left(v \approx v^{\prime}\right)$ に反している。

この矛盾は、式(10)に抋いて，非晶と結晶との直列 モデルの延伸方向の繰返し単位（敞結晶プロック）の数 $n$ が温度 $T_{a}, T_{c}$ において変らないとしていたことに原 因がある。この補正をすると，結晶化度の增加比泽改め て次式で表わされる。

$$
\begin{aligned}
& \chi_{v}\left(T_{c}\right) / \chi_{v}\left(T_{a}\right) \\
& \quad=\left(v, / v^{\prime}\right)\left\{D_{1} D_{2} D_{3}\left(T_{c}\right), D_{1} D_{2} D_{3}\left(T_{a}\right)\right\}\left(n^{\prime} / n\right)
\end{aligned}
$$

ここで $n^{\prime}, n$ はそれぞれ温度 $T_{c}, T_{a}$ における繰返し単位 (敞結晶ブロロク)の数である。

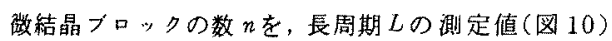

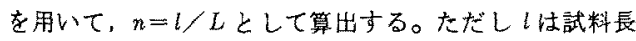

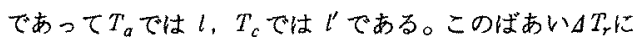

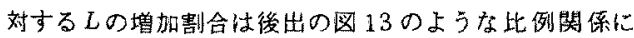
あり，lとLとの測定值から求めた $n$ の割合は $\Delta T_{r}$ とと もに城少する(㘠 11)。古なわち $n^{\prime}=n\left(1-r \Delta T_{r}\right), r=0.508 \pm 0.04\left(\% \mathrm{deg}^{-1}\right)$

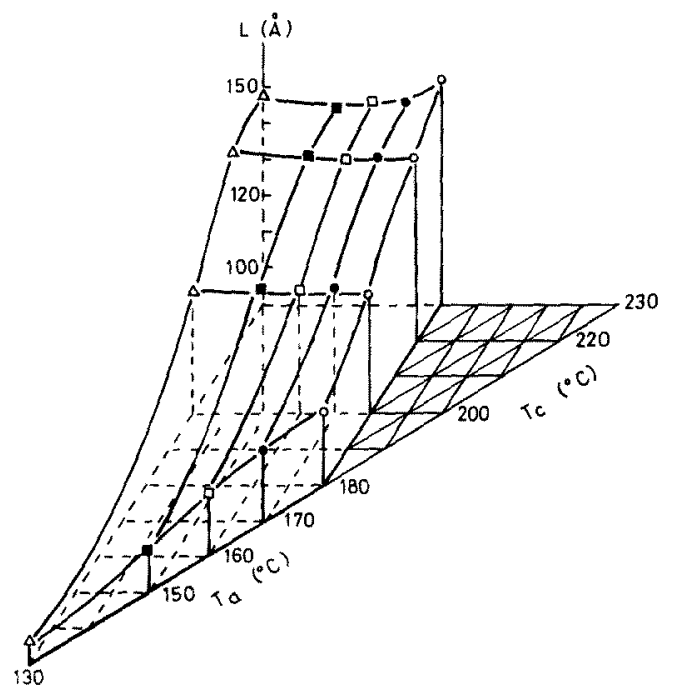

Fig. 10 Variation of the long period $(L)$ with the heat treatment path $\left(T_{a} \rightarrow T_{f}\right)$.

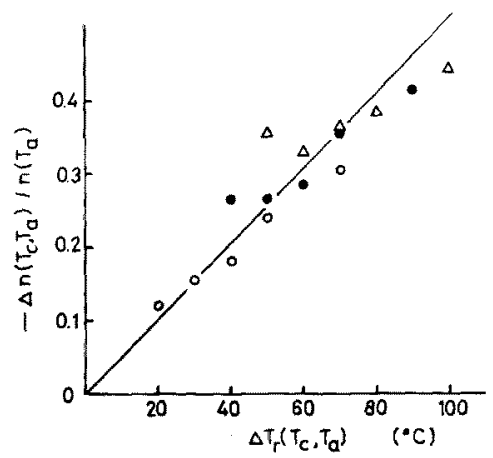

Fig. 11 Rate of decrement of number of crystallite block along the stretched axis, $-\Delta n / n$, as a function of temperature change, $\Delta T_{r}$.

$O\left(T_{c}=200^{\circ} \mathrm{C}\right),-\left(T_{c}=220^{\circ} \mathrm{C}\right), \Delta\left(T_{c}=230^{\circ} \mathrm{C}\right)$.

である。式(13)を式（12）に代入して

$$
\begin{aligned}
& \left(1+\kappa_{v} \Delta T_{r}\right) \\
& =\left(v / v^{\prime}\right)\left(1+\left(\alpha_{1}+\alpha_{2}+\alpha_{3}\right) \Delta T_{r}\right\}\left(1-r \Delta T_{r}\right)
\end{aligned}
$$

をうる。温度係数 $\kappa_{v}, \alpha_{1}, \alpha_{2}, \alpha_{3}$ および れ隹 $\Delta T_{r}=100^{\circ} \mathrm{C} に お い て v / v^{\prime}=1.02$ が得られ，收繀 前後の体積はほ上んど变らず合理的な結果に到達する。 こうして長さ方向の微結晶ブロックの長さが増大し, ブロックの数が減少することは，熱処理による結晶組織 の再編成を意昧する。そのメカ二ズム估次節で考察する ことにして，ここでは収維率 $S=1-(l / l)$ との関係をみ 
ておく。いまめ試料断面で結晶ブロックが占める割合 とすると, 式 $(12) の\left(v / v^{\prime}\right)$ は $\left(v / v^{\prime}\right)=\left(l / l^{\prime}\right)\left(\phi^{\prime} / \phi\right)$ $\left\{D_{2} D_{3}\left(T_{a}\right) / D_{2} D_{3}\left(T_{c}\right)\right\}$ と表わされるから, 同式は

$$
\frac{\chi_{v}\left(T_{c}\right)}{\chi_{v}\left(T_{a}\right)}=\frac{l}{l^{\prime}} \cdot \frac{\phi^{\prime}}{\phi} \cdot \frac{D_{1}\left(T_{c}\right)}{D_{1}\left(T_{a}\right)} \cdot \frac{n^{\prime}}{n}
$$

とかきかえられる。さらに試料の結晶化度に対する全結 晶ブロック長の割合 $D_{1} n / \chi_{v}=\psi$ とおけば, 式 (15)から

$$
S=1-\left(\phi^{\prime} / \phi\right)\left(\psi^{\prime} / \psi\right)
$$

の関係がえら机る。温度差 $\Delta T_{r}=T_{c}-T_{a}$ が大になると， $\phi$ の比は 1 より大となるが山の比は 1 より减少し， $S$ は $\Delta T_{r}$ に対してほぼ直線的に増加する。たとえば $\Delta T_{r}=100$ ${ }^{\circ} \mathrm{C}$ では $S=0.157$ であり, $\psi^{\prime} / \psi=\left(1+\alpha_{1} \Delta T_{r}\right)\left(1-r \Delta T_{r}\right)$ $/\left(1+\kappa_{v} \Delta T_{r}\right)=1.38 \times 0.492 / 1.35=0.503, \phi^{\prime} / \phi=1.67$ である。定性的にいえば， $\Delta T_{r}$ が大になるにつれて結晶 ブロックの側方のヘッッングが向上してめの此が増すけ れども, それ以上に長さ方向ではブロックの成長ないし 合体が進行するため廿の比が隇少し,このことがSの值 を大きくする。

\section{3 熱収縮における微結晶ブロックの再組織}

本節では延伸PETのモルホロジカルな棈造単位として

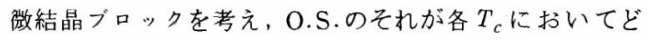
のような組織变化を示すかを、収縮試料のSAXS像と DSCサーモグラムとから検討する。

図 12 に小角回折写真の例を示した。O.S.ではブラッ ク反射が明瞭でなく，束状晶ができていると思われる 収縮試料では， $T_{a}$ の履歴の差はあまり影響がなく, そ

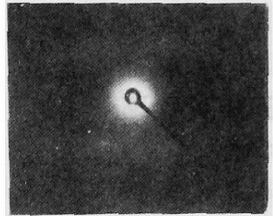

0.S.

$\left(T_{a}=150^{\circ} \mathrm{C}\right)$

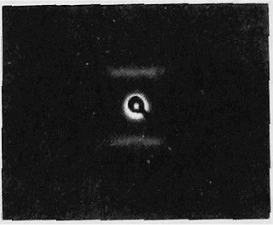

$$
T_{C}=220^{\circ} \mathrm{C}
$$

$\left(\Delta \mathrm{T}_{\mathrm{r}}=70^{\circ} \mathrm{C}\right)$

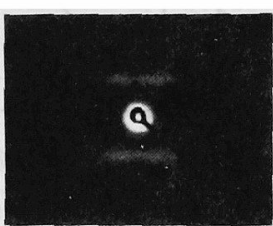

$\mathrm{T}_{\mathrm{C}}=200^{\circ} \mathrm{C}$ $\left(\Delta T_{r}=50^{\circ} \mathrm{C}\right)$

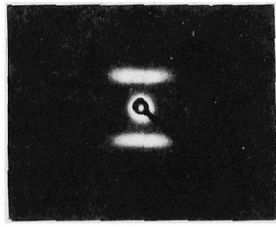

$\mathrm{T}_{\mathrm{C}}=230^{\circ} \mathrm{C}$ $\left(\Delta T_{r}=80^{\circ} \mathrm{C}\right)$
Fig. 12 Effect of heat treatments on the small-angle Xray scattering from pre-crystallized PET films.
の强度は収縮温度 $T_{C}$ によってきまるようである。このば あい四点像が現われ, それの子午線に対する傾角はほぼ 一定で, $T_{c}$ が高いほどやや増している。回折写真から求 めた長周期 $L$ の值は， $\Delta T_{r}=T_{c}-T_{a}$ に比例して増加して 扔り

$$
\begin{aligned}
& L\left(T_{0}\right)=L\left(T_{a}\right)\left(1+\alpha_{L} \Delta T_{r}\right), \\
& \alpha_{L}=0.53 \pm 0.050\left(\% \mathrm{deg}^{-1}\right)
\end{aligned}
$$

の関係がある (図 13 )。また密度 $っ$ と $/ L$ との間には図 14 のような直線関保があり，Lが大きいほど $\rho$ が大きく なっている。これはHosemann ら ${ }^{16)} の$ paracrystal モ デルにおいて熱処理によって微結晶ブロックが再組織さ れ，互に横方向に合体して層状構造が形成される段階に 相当している。したがってわれわれの熱処理温度 $T_{c}$ で はラメラ晶が発達し, 微結晶ブロックは横に連った組織 になっているといえよう。なお Berzuk-Kawaiららう 電子顕微鏡観察によれば, PETの高温熱処理試料は, 徽結晶の $\{k 00\}$ または $\{0 k o\}$ 面が横に連ってラメラ状

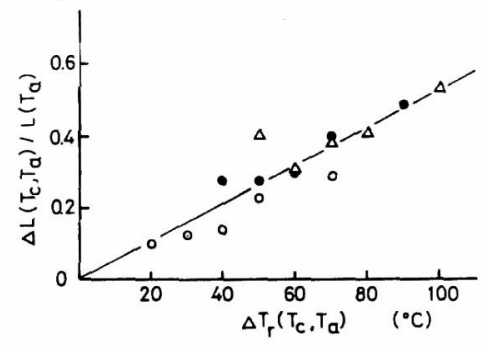

Fig. 13 Rate of increment of long period $\Delta L / L$ as a function of temperature change $\Delta T_{r}=T_{c}-T_{a}$. $O\left(T_{c}=200^{\circ} \mathrm{C}\right), \quad\left(T_{c}=220^{\circ} \mathrm{C}\right), \Delta\left(T_{c}=230^{\circ} \mathrm{C}\right)$.

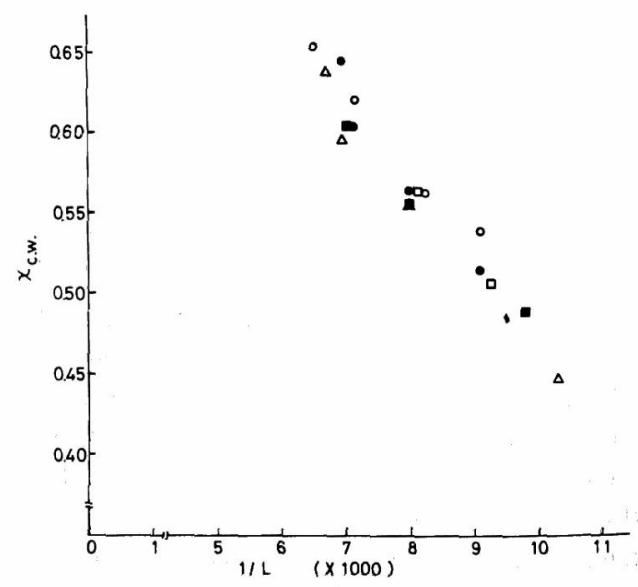

Fig. 14 Plot of the weight fraction crystallinity $\left(x_{c, w}\right)$ against reciprocal of the long period $(L)$. 

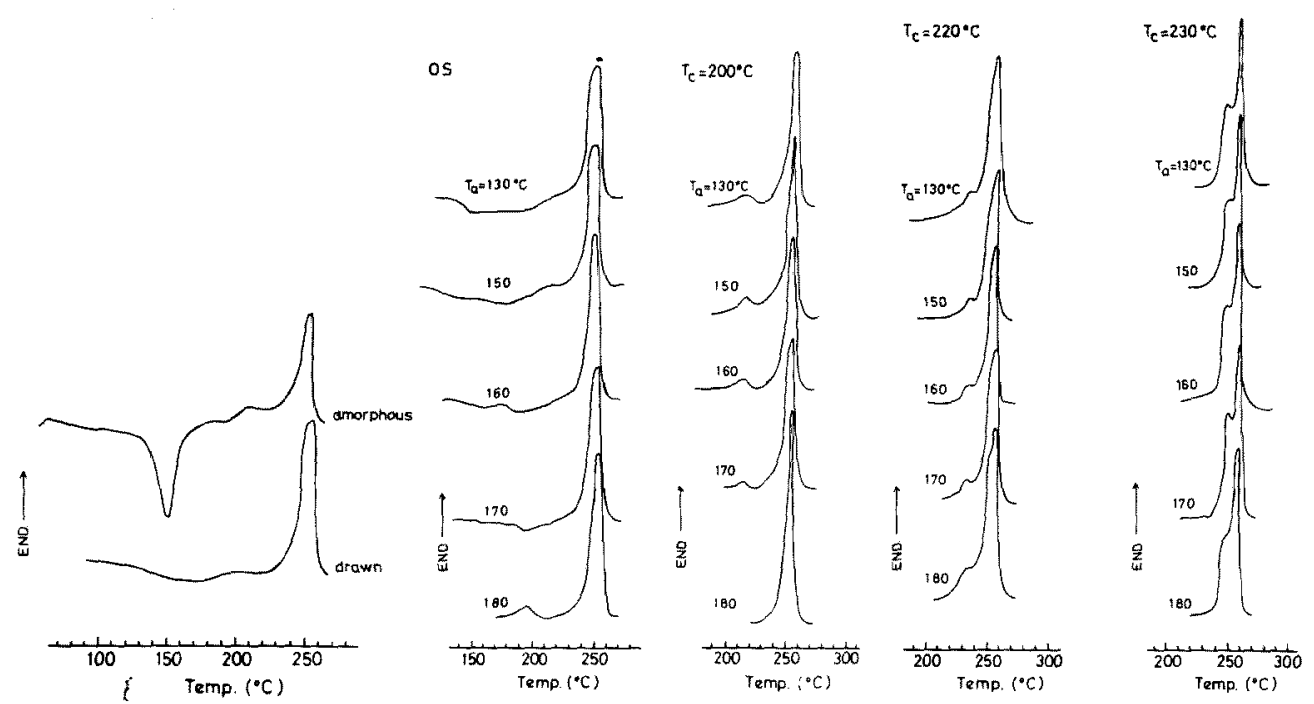

Fig. 15 DSC thermograms of heat treated PET films.

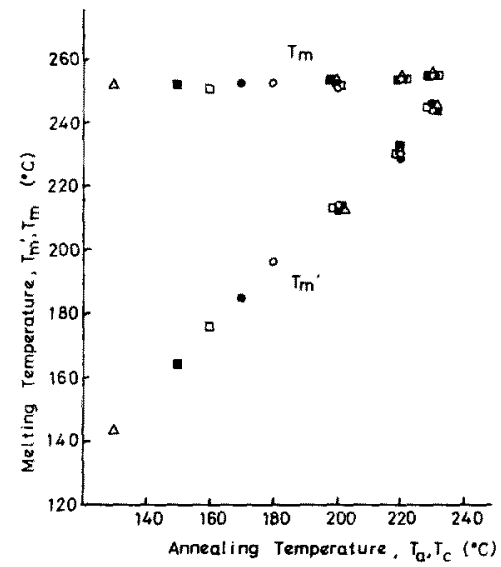

Fig. 16 Endtherm peak temperature (higher one $T_{m}$, lower one $\left.T_{m}{ }^{\prime}\right)$ vs. heat treatment temperature ( $T_{a}$ and $T_{c}$ ).

に再組織されることが鰙められている。

つぎ DSCサーモグムについてみると，図 15に例 示したようにすべての試料について二重ピータが覞測

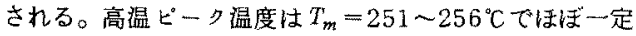

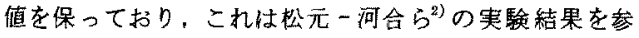
照すると束状晶がラィラ晶に再編成された結晶の融解を あらわし，また低温ピーク温度 $T_{m}{ }^{\prime}$ は図 16に示したよう に熱妧理温度Ta，Teに詨して勾配が䄪1で增大していて， これ怯処理中に発生したラメラ㤥が成長したものの融

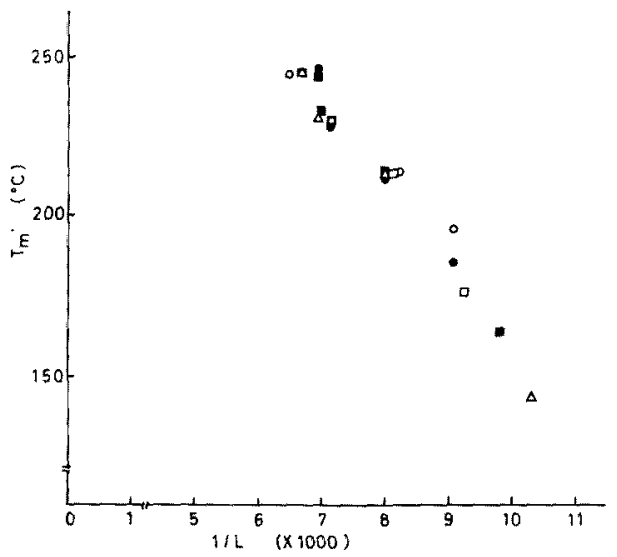

Fig. 17 Plot of the endtherm peak temperature $T_{m}$ ' against reciprocal of the long period $1 / L$.

点であると解积できる年, 17) そして $T_{m}^{\prime}$ は1ノLに対して 直線関係があり(依17)，SAXSの測定結果(四14)飞

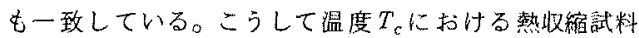
の結晶プロックは贋状のライラ晶に再組織されていると 推定される。

\section{4 収縮による無定形分子鎖の配向变化}

自由長熱処理でラィラ晶ができるばあい，結晶ブロッ ク間の無定形域あるいは比較的不完全な微結晶が，結晶 相にとりこ宋れることによって長さ方向のブロック数が 
减少しつつ,サイズの大きなラメラ状の結晶組織が形成 される。こうして試料長は収縮するがこのときラメラ間 の無定形分子鎖は果して収縮するか緊張するか，またそ の配向係数がどのように变るかを，モデル的に推定して みる。

いま収縮䏠後の無定形域の厚さを $r, r^{\prime}$ とすれば，単 純な直列モデル $(l=r+D)$ では $s=\left\{1-\chi_{v}\left(T_{a}\right)\right\} \beta-\chi_{\nu}$ $\left(T_{a}\right) \alpha_{1} よ り$

$$
\beta=\left\{s+\chi_{y}\left(T_{a}\right) \alpha_{1}\right\} /\left\{1-\chi_{v}\left(T_{a}\right)\right\}
$$

をうる。ここで $\beta$ は無定形域の収縮係数で $r^{\prime}=r(1-$ $\left.\beta \Delta T_{r}\right)$ であ。測定值は $s=0.157 \% \mathrm{deg}^{-1}, \alpha_{1}=0.38$ \% $\mathrm{deg}^{-1}$ であるから $\beta$ は常に正となり，無定形域は短縮 する。また直列モデルにプロック数nの变化索付加すれ अ゙ $(l=n r+n D)$, 改めて $s=r+\left\{1-\chi_{v}\left(T_{a}\right)\right\} \beta-\chi_{v}$ $\left(T_{a}\right) \alpha_{1} よ り$

$$
\left.\beta=\left\{(s-\gamma)+\chi_{v}\left(T_{a}\right) \alpha_{1}\right\} / \mid 1-\chi_{\nu}\left(T_{a}\right)\right\}
$$

である。nの減少倸数 $r=0.508 \% \mathrm{deg}^{-1}$ を用いると，式 (19)は $x_{v}\left(T_{a}\right)<(r-s) / \alpha_{1}=0.92$ の範用で $\beta<0$ とな る。O.S.の結晶化度は $\chi_{v}\left(T_{a}\right)=0.45 \sim 0.55$ であるから このばあいは， $\beta<0 て ゙ r^{\prime}>r$ となり，無定形域は拡大寸 る。じっさいにrの推定値として $(L-D)$ を採ると，乙 の $\Delta T_{r}$ 依存性は图18に示したように直線的に增大して いる。すなっち

$$
\begin{aligned}
& (L-D)_{T_{c}}=(L-D)_{T_{a}}\left(1+\beta_{l} \Delta T_{r}\right), \\
& \beta_{L}=0.65 \pm 0.054\left(\not / \mathrm{deg}^{-1}\right)
\end{aligned}
$$

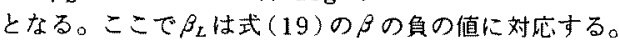

このようにブロック数の変化する直列モデルは無定形 域の幾何学的な拉大を示してくれるけれども，この拡大 がただちに無定形分子鎖の繁張を意味するかどうか忏定 がでない。そこで再組織のさい，結晶の増加分だけ無定

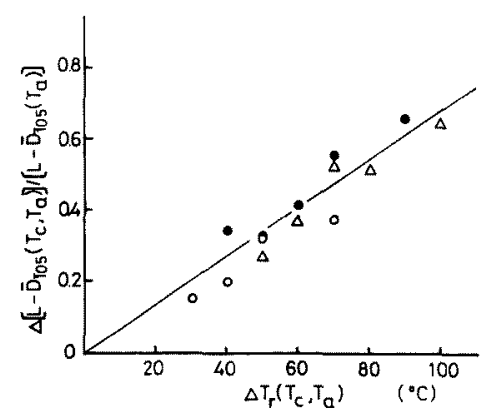

Fig. 18 Relation between the rate of increment of thickness of amorphous region $4(L-\bar{D}) /(L-\bar{D})$ and the heat treatment temperature change $\Delta T_{r}=T_{c}-T_{a} . \quad O\left(T_{c}=200^{\circ} \mathrm{C}\right)$, - $\left(T_{c}=220^{\circ} \mathrm{C}\right), \Delta\left(T_{c}=230^{\circ} \mathrm{C}\right)$.
形域が减少するものとして，同じ分子鎖の質監バランス を考慮して，式(19)の関係を導いてみる。はじめに， 結晶相の体積 $\left(v_{c r}=\chi_{v} v\right)$ が增加し，無定形相の体皘 $\left(v_{a m}\right.$ $\left.=\left(1-\chi_{v}\right) v\right)$ 落相当量減少するとき無定形分子鎮長 $r か ゙$ rに変ったとすれ机

$$
\frac{r}{r^{\prime}}=\frac{1-s \Delta T_{r}}{1-r \Delta T_{r}}\left(1-\frac{\chi_{v}\left(T_{a}\right)}{1-\chi_{v}\left(T_{a}\right)} \frac{\rho_{c}}{\rho_{a}} \kappa_{v} \Delta T_{r}\right)
$$

この結果を式 (19)と比較すると, 近似的に $\kappa_{v}=11-\chi_{v}$ $\left.\left(T_{a}\right)\right\}\left(\beta+\alpha_{1}\right)$ である。これは式(9)と同じである。つ ぎに温度差 $\Delta T_{r}$ に関する自由長熱処理で，結晶相の質量 $\left(m_{c r}=\chi_{w} m\right)$ が堌加した分だけ無定形相の質量 $\left(m_{a m}=\right.$ $\left.\left(1-\chi_{w}\right) m\right)$ が減少するとき，収縮後の無定形分子鎖長 が $\boldsymbol{r}^{\prime \prime}$ とるものとすると

$$
\frac{r^{\prime \prime}}{r}=\frac{1-s \Delta T_{r}}{1-r \Delta T_{r}}\left(1-\frac{\chi_{w}\left(T_{a}\right)}{1-\chi_{w}\left(T_{a}\right)} \kappa_{w} \Delta T_{r}\right)
$$

である。式 (21)，(22)をくらべると $\kappa_{w}>\kappa_{v} よ り r^{\prime}>r^{\prime \prime}$ である(ただし $\left\{\chi_{v} /\left(1-\chi_{v}\right)\right\}\left(\rho_{c} / \rho_{a}\right)=\chi_{w} /\left(1-\chi_{w}\right) \infty$ 関係を用いた)。このことは自由長熟処理によって，Ta おける無定形分子鎖の伸率 $\varepsilon_{a} か ゙ d \varepsilon_{a}=\left(r^{\prime}-r^{\prime \prime}\right) / r^{\prime}$ だけ增 加したものと解秎することができる。すなわち

$$
\Delta \varepsilon_{a}=\frac{\chi_{w}\left(T_{a}\right)}{1-\chi_{w}\left(T_{a}\right)}\left(\kappa_{w}-\kappa_{p}\right) \Delta T_{r}
$$

温度 $T_{a}=130^{\circ} \mathrm{C}$ から $180^{\circ} \mathrm{C} の$ 範囲で $\chi_{t o}\left(T_{a}\right)=0.45$ 加ら 0.55 に， $\chi_{w} /\left(1-\chi_{w}\right)=0.82$ から 1.22 に変化するのに 対して, 測定檤の $\kappa_{w}=0.41 \% \mathrm{deg}^{-1}, \kappa_{v}=0.35 \% \mathrm{deg}^{-1}$ を用いると, 式 (23)の $\Delta \varepsilon_{a} / \Delta T_{r}$ の值は 0.05 加ら $0.07 \%$ $\mathrm{deg}^{-1}$ に僅かながら堌大する。このことは結晶化度の大 きなO.S.ほど同じ $\Delta T_{r}$ の温度差の熟呚理では $\Delta \varepsilon_{a}$ が大き くなり，その無定形分子鎖は一層祭張することを示して いる。

以上により， $\Delta T_{r}=T_{c}-T_{a}$ が大きいほど試料の収樎率 Sが大きくなり，このとき無定形分子鎖は緊張してその 配向保数は増加することが推諭される。しかしこの結果 はS amuels ${ }^{11}$ が無定形領域の収縮によって試料の収樎 率が定められるとする結論とは一致しない。われわれの 試料では，自由長熱処理で結晶化度が增加するほど長さ 方向の結晶ブロックは大きくなりその綝返し数が減少し て，結晶内への無定形分子鎖の取込みが進行することを 前提としているからである。

\section{文献}

1) A. Siegmann, P. H. Geil; J. Macromol. Sci - Phys, B4 (3), 557 (1970).

2) 松元, 池上, 河合, 前田: 工化, 73, 2442(1970), L. I. Bezruk, T. Kawai, Yu. S. Lipatov: Polymer J., 6, 376 (1974)

3) D. C. Prevorsek, G. A. Tirpak, P. H. Harget, A. C. 
Reimschuessel: J. Macramol. Sct. - Phys., B9 (4), 733 (1974).

4）大矢，山本，斉藤，木下：㵶学誌，31，T508 (1975).

5) K. K. Mocherla, J.P. Bell: J. Polymer Sci - Phys. ed., 11, 1779 (1973).

6)石鍋, 篠田, 营生, 石川：舅化，29，56(1972)。

7) E. Ito, T. Takamatsu: RPPPJ, 16, 319 (1973)

8) 上田, 温品：高化, 21,337 (1964). 0

9) 松元, 江原, 他上, 河合, 前由: 㵶学誌, 25,5 (1969)

10) K. Suehiro, T. Terashima, M. Takayanagi: J. Material Sci. 9, 1563 (1974).
11) R. J. Samuels: J. Macromol, Sci, - Phys, B8 (1-2), $41(1973)$.

12) 池田,三石：高化，24, 378 (1967)

13) J.H. Dumbleton, B.B. Bowles: J. Polymer Sci., A-2, 4, 951 (1966).

14）谷建，山本，斉藤，木下：繊維学会年次大会满演要 旨等，30 (1975)

15) C.J. Heffelfinger, E. L. Lippert, Jr.: J. Appl. Polymer Sci. 15, 2699 (1971).

16) J. Loboda-Cackovic, R. Hosemann, W. Wilke: Kolloid-Z, u, Z. Polymer, 235, 1161 (1962).

17) 油林，折户，山田：工化，69、1798 (1966).

\title{
メタリックワイヤのゲージおよび溝の媣さが圧力損失 並びに流体摩擦係数に及ぼす影響についで
}

\author{
京都工䒧瀻維大学繊維学部細
大阪大学工学部
NG AND THE GROOVE DEPTH OF
UPON THE PRESSURE DROP
CTION FACTOR \\ By Juzo Hosokawa** and Akira Horikawa*** \\ ** (Kyoto University of Industrial Art and Textile Fibres, \\ Matsugasaki, Sakyo-ku, Kyoto-City, Japan) \\ *** (Osaka University, Suita, Osaka Pref, Japan)
}

When the setting between the top of the metallic or model wire and the plain plate and the depth from the top of wire to the bottom of groove are changed respectively, the friction factor $\lambda$ of wire is obtained by measuring the drop in pressure at different values of velocities of the air in a given length of a very thin rectangular tube in the same manner as mentioned in the previous report." )

From the relationships between the drop in pressure $A P$ in a given length of the tube and the mean velocity of the air $\bar{u}$ and those between $\lambda$ and $R e$ for laminor flow $(R e<1000$ ), the following results are obtained:

1) When the setting is changed, the drop in pressure at a mean velocity is maximum in the minimum setting between the top of wire and the plain plate.

2) When the depth from the top of wire to the bottom of groove is changed, the drop in pressure increases with decreasing the depth of groove even in the constant setting. Moreover, in the relation between $\lambda$ and $R e$ expressed as $\lambda=K / R e$, the higher value of $K$ is obtained in case of the shallower groove.

From these results mentioned above, the effective carding action can be expected pneumatically between the plain plate and the metallic wire by minimizing the setting and by using the wire having the shallowest groove.

(Received October 21, 1975)

\footnotetext{
*この報交を「カードの高速化に関する研觉(第6報), Studies on high High Speed Carding (Part6)」と する。
} 